Article

\title{
The Usage of Public Transport and Impact of Satisfaction in the European Union
}

\author{
Audronè Minelgaitè, Renata Dagiliūtė $(\mathbb{D})$ and Genovaitè Liobikienè *(1) \\ Department of Environmental Sciences, Vytautas Magnus University, Vileikos St. 8, LT-44404 Kaunas, Lithuania; \\ audrone.minelgaite@vdu.lt (A.M.); renata.dagiliute@vdu.lt (R.D.) \\ * Correspondence: genovaite.liobikiene@vdu.lt; Tel.: +370-6474-1273
}

Received: 22 September 2020; Accepted: 30 October 2020; Published: 3 November 2020

check for updates

\begin{abstract}
The main objective of this paper was to analyse comprehensively the urban public transport usage, satisfaction levels and the satisfaction impact on usage of public transport in European Union (EU) countries. Results revealed that the usage of urban public transport in all EU countries is rather low and significantly depends on economic development level. The satisfaction levels measured as comfort and safety, ticket price, frequency and reliability and amenities at stops and stations significantly differed among EU countries as well. In a half of the EU countries, the satisfaction with ticket price and the time to the station had significant impacts on usage of urban public transport. Meanwhile, the satisfaction with reliability, public transport frequency and comfort and safety had significantly influenced urban public transport usage only in one-third of EU countries. In the majority of EU countries, women and older respondents more often tended to use urban public transport. Next to improvement of public transport service, a variety of policy measures should be applied, from awareness rising and image improvement to the review of pricing policies both of public transport and of parking fees.
\end{abstract}

Keywords: public transport usage; satisfaction level; European Union; sustainability; economic development level

\section{Introduction}

The transport sector contributes to air pollution, energy consumption, greenhouse gas emissions [1-4], traffic congestion, road accidents, increased noise [5] and related health impacts. Hence, the promotion of urban public transport (UPT) usage should contribute to the reduction of these problems [6-11] and has the potential benefit of enhancing social inclusion [12-14] and contributes to seeking sustainability [11,15-17]. Thus, the UPT service is the main aspect of a sustainable transportation system in the world including in European Union (EU) countries [10,18].

However, referring to the Eurostat [19] and the European Platform on Mobility Management [20] reports, the share of public transport in 2011 and 2012 in EU countries was only 16-17\% of the total passenger travel. Therefore, the main aims of the European transport policy are to increase public transport usage and to decrease the usage of private cars [21]. The European Commission supported a big project A MEasurement Tool to determine the quality of the Passenger EXperience (METPEX), which aims to measure the determinants of the passengers' experience and service quality including public transport [22,23]. This project encompassed eight EU cities and the results were presented in a vast number of research studies [18,23-29]. However, to the best of our knowledge, at the country level the UPT satisfaction and usage were scarcely analysed. Furthermore, none of research analysed the situation and determinants of public transport usage in all EU countries jointly. Therefore, the aim of this paper is to analyse comprehensively the urban public transport usage, satisfaction levels and the 
satisfaction impact on usage of public transport in the EU. This analysis can make a great contribution to the formation and implementation of successful sustainable transport policy in all EU countries.

\section{Literature Review}

\subsection{UPT Satisfaction and Its Categories}

The measurement of UPT satisfaction is described as a consequence of the quality offered by the urban transport system service [30]. However, authors analysing UPT satisfaction and transport sector quality considered various categories. Efthymiou and Antoniou [31] separated satisfaction factors into quality of service, transfer quality and service production. Chica-Olmo et al. [32] summarized quality components in two categories: (a) the technical dimension and (b) the functional dimension or "comfort" and "services supply factors". Ngoc et al. [33] classified satisfaction into four categories: comfort and security, service quality, planning quality and reliability. Comparing the users' satisfaction of public transport, Fellesson and Friman [34] found that satisfaction is affected by four factors: (a) comfort, (b) staff, (c) system and (d) safety. Lois et al. [35] classified factors as transfer conditions, information, safety and security, emergency, design and image of services and comfort. Şimşekoğlu et al. [36] separated quality attributes into flexibility, convenience and safety and security. In their literature review, Chowdhury and Ceder [37] summarised factors as (a) safety and security, (b) reliability, (c) transfer time (walking and waiting), (d) information systems for users, (e) ticketing and fare systems, (f) comfort and (g) amenities at interchanges/stations. Friman and Gärling [38] and Gärling et al. [39], analysing the quality of UPT service, suggested we include and evaluate the satisfaction level as a critical indicator of UPT service quality [32] encompassing the image of the operator, travellers' expectations and the perceived service quality $[10,40,41]$.

Thus, the literature review reveals that there is no one classification of UPT satisfaction categories. In this paper we suggest the classification of satisfaction into four categories: (1) frequency and reliability, (2) comfort and safety, (3) price of tickets and (4) amenities at stops and stations. Furthermore, considering that expectations of users (or satisfaction of UPT service) vary significantly among different countries [33], it was important to analyse how different categories of service satisfaction influence UPT usage in various EU countries.

The impact of UPT service quality [16,42-45] and separate components of service quality on the general satisfaction of public transport services and the characteristics of commuters [10,32,46-50] are extensively analysed. Considering EU countries Chica-Olmo et al. [32] and Lois et al. [35] analysed the satisfaction of public service quality factors in Spain, Mouwen [51] in the Netherlands, Abenoza et al. [10], Cats et al. [31] and Jenelius [52] in Sweden and Fiorio et al. [45] in 33 European cities. Meanwhile, the impact of satisfaction regarding public transport services on usage of UPT has been analysed rather scarcely $[16,51,53]$.

\subsection{The Determinants of Usage of UPT}

The usage of UPT very much depends on the service quality, accessibility and affordability. Hence, the improvement of service quality is the main component of UPT usage [1,2,16,36,54,55]. Considering the studies concerning EU countries, Woods and Masthoff [5] compared public transport usage, car driving and cycling experience in Finland, Spain and Italy. However, the primary question for transport operators and authorities, which UPT service quality attributes are the most important for people and could contribute to the enhancement of UPT usage in EU countries, remains [33]. Additionally, in line with good levels of service quality, extensive coverage was the most essential component of the public transport system $[5,10,21,37,56]$. Brons and Rietveld [57] found that low accessibility negatively influenced the overall assessment of public transport usage. Therefore, it is vital to continue to invest not only in a reliable, comfortable, safe and flexible, but also an accessible UPT [50,58]. Access to public transport is evaluated as perceived walking time to and from stops and stations $[37,59,60]$. The distance (time) to stations is particularly important for old people [61] and UPT interchanges [21]. Meanwhile, 
Şimşekoğlu et al. [36] found that time from home to nearest stations insignificantly influenced the usage of public transport in Norway.

Socio-demographic variables are also essential aspects in terms of UPT usage [37,50,62]. According to Eurobarometer reports [63], women and young people (particularly students) were the major user groups of public transport. Buehler and Pucher [64] have found a slight growth in use among young men. Meanwhile, Woods and Mashthoff [5] found no significant age and gender differences for usage of public transport in three EU countries. Şimşekoğlu et al. [36] revealed that age, but not gender, influences the usage of public transport in Norway.

\section{Methods and Data}

The satisfaction and UPT usage in the EU were analysed referring to the "Europeans' satisfaction with urban transport" survey which was performed by Eurobarometer in 2014 [65]. The survey provided the information about individuals' attitudes and tendencies of behaviour related to urban public transport. Respondents from all EU countries participated in the Eurobarometer survey. Therefore, this survey is very useful providing the data about public transport usage in the whole of the EU. The respondents in separate EU countries were interviewed via telephone. The survey encompassed respondents from different demographic and social groups. The detailed interview method and confidence level of intervals were presented in the European Commission report [65]. In our analysis we included all EU countries except Luxemburg (AT-Austria, BEBelgium, BG-Bulgaria, CY-Cyprus, CZ-Czech Republic, DK-Denmark, EE-Estonia, ES-Spain, FL-Finland, FR-France, GE-Germany, GR-Greece, HR-Croatia, HU—Hungary, IE-Ireland, IT-Italy, LV—Latvia, LT—Lithuania, MT-Malta, NL-Netherlands, PL—Poland, PT—Portugal, RO—Romania, SK—Slovakia, SL—Slovenia, SE—Sweden, and UK—United Kingdom).

Our study provides more in-depth analysis, applying the factor analysis the satisfaction categories (constructs) were distinguished and using the regression analysis the determinants of UPT were analysed. The UPT usage was estimated by the answers to the question: "How often do you travel by urban public transport: bus, metro, tram, etc." The responses were from 1-daily/almost daily to 7-never. To evaluate the impact of economic development on UPT usage (mean level of UPT usage in separate country) the GDP per capita in purchasing power parity (constant 2011 international dollars) in 2014 was used. To evaluate this relationship, the Spearman correlation coefficient was applied.

The satisfaction of UPT service by applying factor analysis was separated into four categories: comfort and safety, frequency and reliability, ticket price and amenities at stops and stations. The items of satisfaction scales are presented in Table 1. All constructs were measured using a five-point Likert scale ranging from very satisfied to very dissatisfied. The reliability statistics by applying Cronbach's alpha are presented in Table 2. The Cronbach's alphas vary from 0.55 to 0.87 . To denote strong reliability among measures Cronbach's alpha for constructs must exceed the cut-off point of 0.7 [66,67]. Thus, from the analysis, Germany, Portugal, Finland, Latvia, Cyprus and Malta were excluded because the values were less than 0.7 , which revealed that analysed constructs were unreliable. For the latter two countries, there was a lack of ticket price satisfaction data.

To evaluate the determinants of urban public transport (UPT) usage, a generalized linear model was applied. This method was used because the model has the possibility of including the categorized factors such as gender and it helps to assess the factors that influence UPT usage the most and directly. Referring to the proposed model presented in Figure 1, we analysed the impact of satisfaction levels, time from home to the nearest station or stop (1-less than $10 \mathrm{~min}$ to 4 -more than an hour) and social-demographic variables such as age and gender on UPT usage. 
Table 1. Items of UPT (urban public transport) service satisfaction scales.

\begin{tabular}{|c|c|}
\hline Construct & Items \\
\hline Frequency and reliability & $\begin{array}{l}\text { - I am satisfied with the frequency of service } \\
\text { - } \quad \text { I am satisfied with punctuality and reliability }\end{array}$ \\
\hline Comfort and safety & $\begin{array}{l}\text { - I am satisfied with the routes taken by the different urban lines } \\
\text { - I am satisfied with passenger security } \\
\text { - I am satisfied with the cleanliness and good maintenance of } \\
\text { vehicles carriages }\end{array}$ \\
\hline Price of tickets & $\begin{array}{l}\text { - I am satisfied with the ease of buying tickets } \\
\text { - } \quad \text { I am satisfied with the price of the tickets } \\
\text { - I am satisfied with availability of tickets for a journey using several } \\
\text { modes (e.g., tram, metro, bus, local trains) } \\
\text { - I am satisfied with possibilities to take routes by the different } \\
\text { urban lines }\end{array}$ \\
\hline Amenities at stop and station & $\begin{array}{l}\text { - I am satisfied with the provision of information about timetables } \\
\text { - I am satisfied with amenities for passengers at stops and stations (e.g., } \\
\text { shelter, seats) } \\
\text { - I am satisfied with the cleanliness and good maintenance of stops } \\
\text { and stations }\end{array}$ \\
\hline
\end{tabular}

Table 2. The Cronbach's alpha of scales.

\begin{tabular}{|c|c|c|c|c|}
\hline & $\begin{array}{l}\text { Frequency and } \\
\text { Reliability }\end{array}$ & $\begin{array}{l}\text { Comfort and } \\
\text { Safety }\end{array}$ & $\begin{array}{l}\text { Amenities at Stop } \\
\text { and Station }\end{array}$ & $\begin{array}{l}\text { Price of } \\
\text { Tickets }\end{array}$ \\
\hline $\mathrm{FR}(\mathrm{n}=1004)$ & 0.71 & 0.77 & 0.74 & 0.70 \\
\hline $\mathrm{BE}(\mathrm{n}=1000)$ & 0.77 & 0.74 & 0.70 & 0.70 \\
\hline NL $(n=1002)$ & 0.81 & 0.82 & 0.75 & 0.76 \\
\hline $\mathrm{GE}(\mathrm{n}=1000)$ & 0.62 & 0.65 & 0.68 & 0.64 \\
\hline $\mathrm{IT}(\mathrm{n}=1001)$ & 0.79 & 0.74 & 0.78 & 0.70 \\
\hline $\mathrm{DK}(\mathrm{n}=1008)$ & 0.76 & 0.82 & 0.73 & 0.70 \\
\hline $\operatorname{IE}(n=1000)$ & 0.85 & 0.81 & 0.79 & 0.75 \\
\hline $\mathrm{UK}(\mathrm{n}=1007)$ & 0.79 & 0.71 & 0.70 & 0.70 \\
\hline $\mathrm{GR}(\mathrm{n}=1000)$ & 0.78 & 0.77 & 0.77 & 0.74 \\
\hline $\mathrm{ES}(\mathrm{n}=1001)$ & 0.75 & 0.74 & 0.74 & 0.72 \\
\hline $\mathrm{PT}(\mathrm{n}=1002)$ & 0.67 & 0.60 & 0.58 & 0.56 \\
\hline $\mathrm{FL}(\mathrm{n}=1005)$ & 0.59 & 0.66 & 0.64 & 0.72 \\
\hline SE $(n=1000)$ & 0.75 & 0.76 & 0.76 & 0.74 \\
\hline $\operatorname{AU}(n=1001)$ & 0.76 & 0.76 & 0.73 & 0.73 \\
\hline$C Y(n=501)$ & 0.69 & 0.53 & 0.57 & No data \\
\hline$C Z(n=1000)$ & 0.73 & 0.74 & 0.70 & 0.74 \\
\hline $\mathrm{EE}(\mathrm{n}=1000)$ & 0.71 & 0.79 & 0.79 & 0.75 \\
\hline $\mathrm{HU}(\mathrm{n}=1003)$ & 0.75 & 0.76 & 0.71 & 0.74 \\
\hline $\operatorname{LV}(\mathrm{n}=1001)$ & 0.55 & 0.62 & 0.67 & 0.56 \\
\hline $\mathrm{LT}(\mathrm{n}=1000)$ & 0.78 & 0.72 & 0.73 & 0.72 \\
\hline $\mathrm{MT}(\mathrm{n}=500)$ & 0.83 & 0.80 & 0.74 & No data \\
\hline PL $(n=1001)$ & 0.81 & 0.84 & 0.83 & 0.80 \\
\hline SK $(n=1003)$ & 0.85 & 0.87 & 0.83 & 0.83 \\
\hline $\mathrm{SL}(\mathrm{n}=1023)$ & 0.78 & 0.83 & 0.82 & 0.78 \\
\hline $\mathrm{BG}(\mathrm{n}=1000)$ & 0.79 & 0.81 & 0.74 & 0.72 \\
\hline $\mathrm{RO}(\mathrm{n}=1025)$ & 0.79 & 0.79 & 0.70 & 0.75 \\
\hline $\mathrm{HG}(\mathrm{n}=1005)$ & 0.79 & 0.81 & 0.79 & 0.79 \\
\hline
\end{tabular}




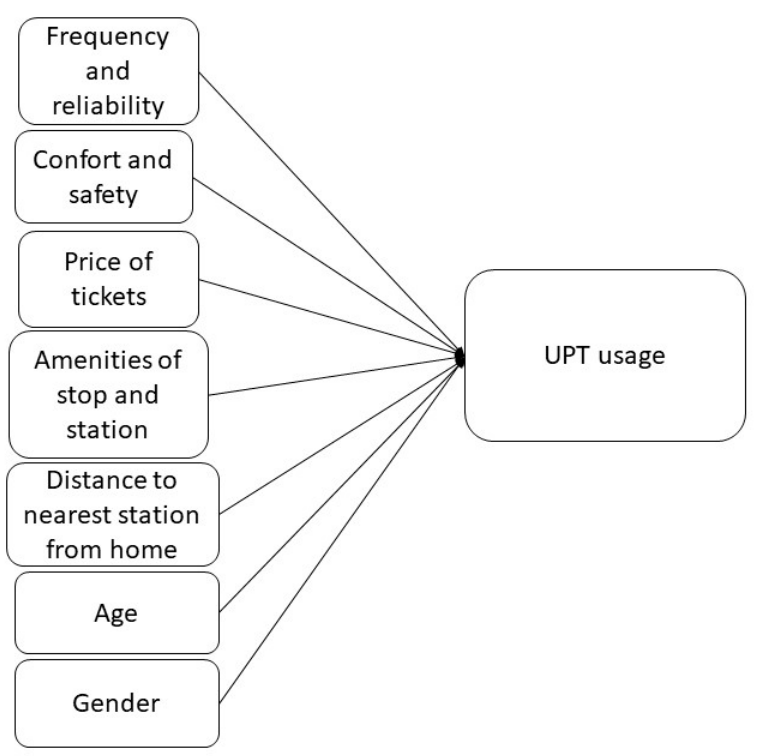

Figure 1. Proposed model.

\section{Results and Discussion}

\subsection{The Tendencies of UPT Usage and Satisfaction}

The level of UPT usage is rather low in EU countries. Across the EU, only $15.7 \%$ of respondents stated that they used UPT almost daily, and $11.1 \%$ said several times per week. Even $25 \%$ of respondents declared that they never used UPT and $10.9 \%$ used it only once per year or less. This shows that the promotion of UPT in EU countries still is a very serious challenge seeking a sustainable transportation system.

Nevertheless, a large variation was observed in terms of UPT usage within EU countries. Hungary, Latvia, the Czech Republic and Romania are the countries where the level of UPT usage was the highest. Meanwhile, in Cyprus, the level of UPT usage was the least: $62.7 \%$ of respondents never used UPT. In France and the Netherlands, citizens seldom used UPT as well (Figure 2). Therefore, particularly in these countries, more attention should be paid to trigger and enhance the usage of UPT.

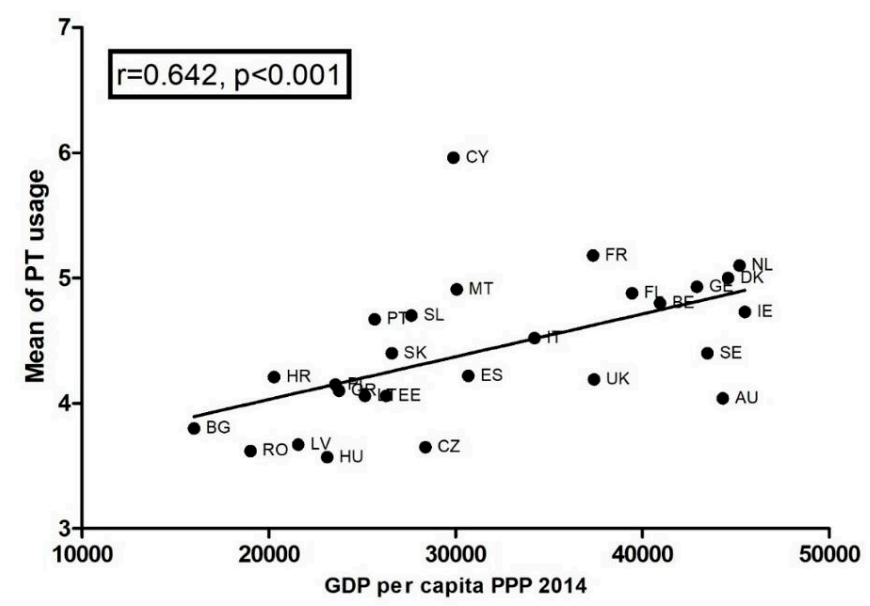

Figure 2. Relationship between mean values of UPT usage (1-daily/almost daily, 7-never use PT) and GDP level.

Furthermore, the results showed that the level of UPT usage significantly depended on the level of economic development of the country (Figure 2). Thus, in richer EU countries, citizens tended to more seldomly use UPT compared with less affluent EU countries. This result contradicts the findings 
of Invardson and Nielsen [68]. However, their study focuses on 48 European metropolitan areas in large cities and only in economically developed countries. In our study, the poorest EU countries, such as Romania, Bulgaria and Croatia were included, where the GDP level was more than two times less than in established EU countries, and we analysed the impact of general economic development level of countries on the mean of UPT usage. One of the reasons that in poorer EU countries citizens used more UPT could be that in these countries not all people could afford to have a car, particularly very young and old people.

Furthermore, in poorer countries, usually, a family has only one car, and UPT is a good alternative for respondents without access to a car. Eurobarometer [63] and Friman et al. [50] highlighted that major user groups of UPT households are without access to cars. Moreover, the cost of public travel is cheaper and UPT services are attractive relative to private vehicles [17,69], especially in lower-income countries. However, the problem could emerge when less developed EU countries achieve the income level of more established EU countries. Therefore, considering the growing mobility it is important to integrate actions involving change of travelling behaviour of residents and a significant increase in the share of journeys by UPT. To reach those targets various UPT attributes must be addressed and considered.

The accessibility and quality of UPT service are within the main factors, which can enhance the level of UPT usage or promote residents to rethink their traveling behaviour. In terms of time to the nearest station from home, the time to get to the nearest stop differed among EU countries. In Bulgaria, Sweden, Denmark and the Netherlands most of the respondents stated that from home to the nearest station it takes $\leq 10 \mathrm{~min}$. Meanwhile, in Croatia, Slovenia and France, the time from home to the nearest station was the longest (Figure 3).

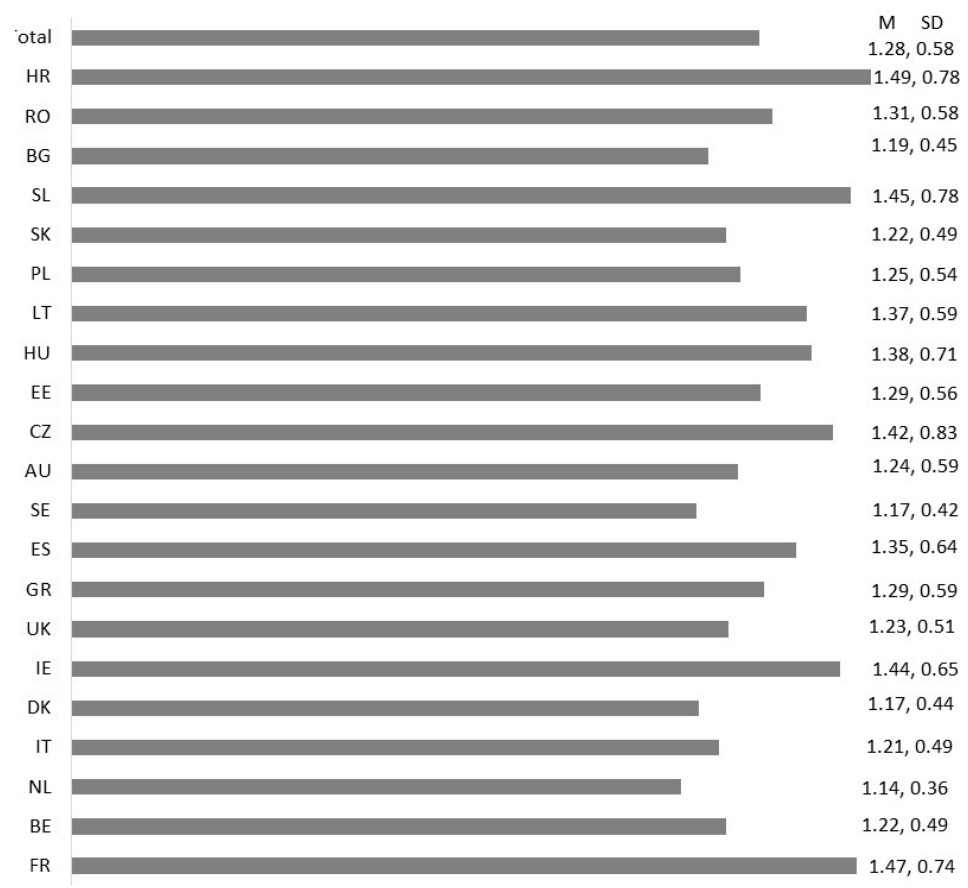

Figure 3. The time to the nearest UPT station from home in EU countries.

The time to the nearest station is particularly important for people with physical disabilities. For older people, walking time to stops should not exceed five minutes [61]. However, it is recommended that the standard distance between stations should be between 1 and $1.4 \mathrm{~km}$ [56]. Thus, the reduction of the time from home to the nearest stop and station is rather difficult and requires compatibility with all parties.

Analysing the satisfaction level of separate UPT quality categories, the results showed that the satisfaction level of reliability, public transport frequency, comfort and safety, ticket price and amenities 
at stops and stations also significantly differed among EU countries. From Figure 4, we see that in countries such as the Czech Republic, United Kingdom, Austria and Estonia where citizens were somewhat satisfied with frequency and reliability, they also were satisfied with comfort and safety and amenities of stops and stations. These results reveal that some governmental institutions and UPT companies in the EU invest and develop separate quality aspects simultaneously. However, respondents were the least satisfied with these categories in Bulgaria, Italy and Greece. Therefore, in the latter countries, particular attention should be paid to the improvement of these UPT quality categories.
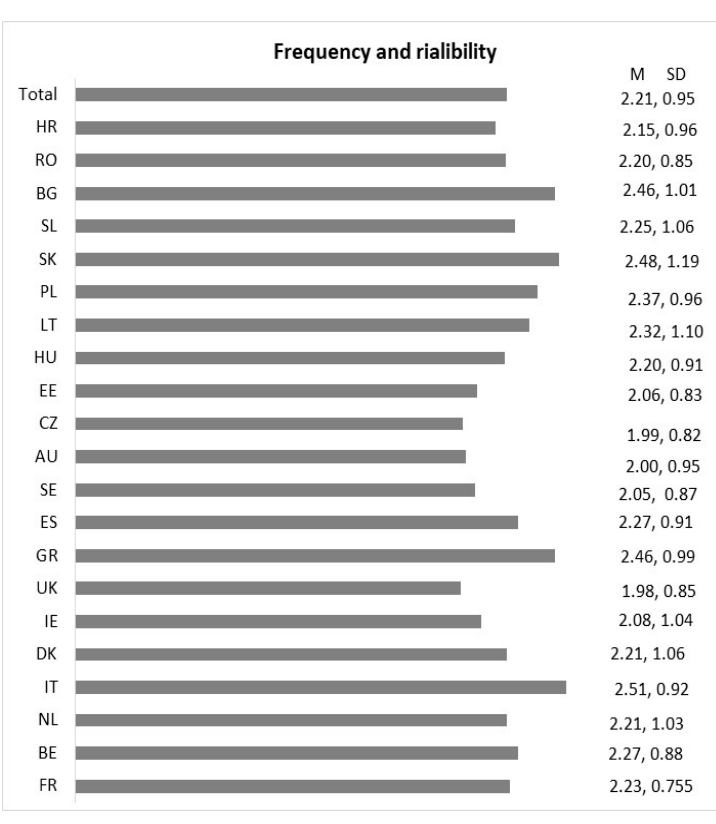

Amenities of stop and stations

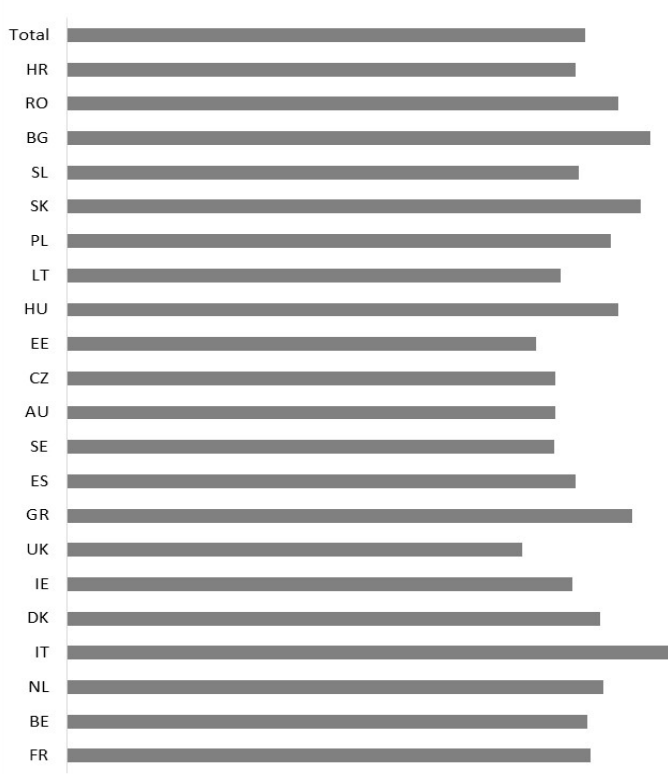

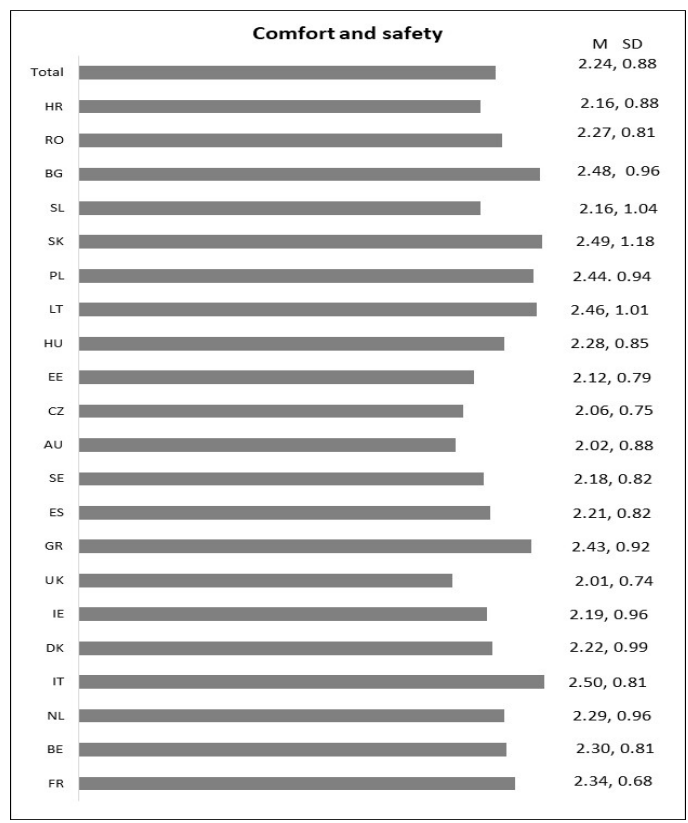

Price of tickets

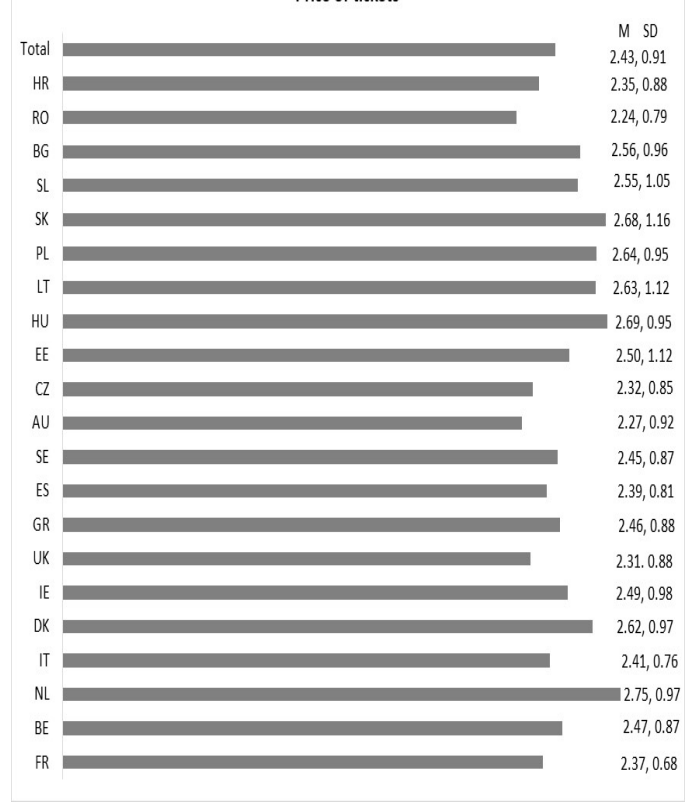

Figure 4. The level of UPT satisfactions in EU countries.

In terms of satisfaction with the ticket price, from all categories of satisfaction, respondents were the least satisfied in the Netherlands, Slovakia and Hungary. Citizens stated that they were rather satisfied with price level only in Austria and Romania. However, to enhance the level of UPT usage, one does not need to improve all quality categories at once. In the next section, we evaluate which of 
the UPT service satisfaction categories are the most important for people and could contribute to the enhancement of UPT usage in EU countries the most.

\subsection{Determinants of UPT Usage in EU Countries.}

Applying the regression analysis, results revealed that not all satisfaction categories are essential to UPT usage behaviour. Furthermore, in different EU countries, the dissimilar determinants significantly influenced UPT usage. Therefore, to enhance the ridership of UPT, each EU country should also consider its peculiarities. As we see from Table 3, in half of the EU countries (11 of 21 countries), age significantly influenced UPT usage. Thus, in these EU countries, older people tended to use UPT more. Furthermore, in half of the EU countries, women used UPT more often. How to promote the usage of UPT for young people and men is a challenge. The main suggestions could be to increase the image of UPT users and introduce some economic or administrative incentives (e.g., limitation of car usage in the city centre, park and ride schemes).

Table 3. Regression results of UPT usage.

\begin{tabular}{|c|c|c|c|c|c|c|c|c|}
\hline & $\begin{array}{l}\text { Amenities at Stop } \\
\text { and Station }\end{array}$ & $\begin{array}{l}\text { Price of } \\
\text { Tickets }\end{array}$ & $\begin{array}{l}\text { Frequency } \\
\text { and } \\
\text { Reliability }\end{array}$ & $\begin{array}{l}\text { Comfort } \\
\text { and } \\
\text { Safety }\end{array}$ & $\begin{array}{l}\text { Time to the Nearest } \\
\text { Station from Home }\end{array}$ & Age & Gender & $\mathbf{R}^{2}$ \\
\hline FR & 0.005 & 0.416 & 0.080 & -0.050 & 0.464 & 0.233 & 0.003 & 0.098 \\
\hline $\mathrm{BE}$ & 0.149 & 0.083 & 0.062 & 0.419 & 0.262 & 0.094 & -0.346 & 0.080 \\
\hline NL & -0.095 & 0.171 & 0.260 & 0.331 & -0.123 & 0.165 & -0.198 & 0.169 \\
\hline IT & 0.019 & 0.432 & -0.177 & 0.185 & 0.092 & 0.047 & -0.298 & 0.034 \\
\hline DK & -0.126 & 0.183 & 0.296 & 0.321 & 0.262 & 0.116 & -0.742 & 0.191 \\
\hline IE & 0.301 & -0.107 & 0.146 & 0.224 & 0.475 & 0.190 & -0.238 & 0.151 \\
\hline UK & 0.118 & -0.229 & -0.045 & 0.759 & 0.470 & -0.030 & -0.028 & 0.071 \\
\hline GR & 0.173 & 0.698 & -0.396 & 0.202 & 0.393 & 0.195 & -0.649 & 0.164 \\
\hline ES & 0.042 & 0.566 & -0.221 & 0.221 & 0.473 & 0.175 & -0.688 & 0.113 \\
\hline SE & 0.003 & 0.841 & 0.024 & 0.015 & 0.305 & 0.171 & -0.560 & 0.184 \\
\hline $\mathrm{AU}$ & 0.136 & 0.795 & -0.142 & 0.090 & 0.379 & 0.038 & -0.083 & 0.167 \\
\hline CZ & 0.045 & 0.318 & 0.285 & 0.185 & 0.597 & 0.026 & -0.417 & 0.160 \\
\hline EE & 0.406 & 0.224 & 0.199 & 0.193 & 0.444 & -0.002 & -0.469 & 0.187 \\
\hline $\mathrm{HU}$ & -0.098 & -0.178 & 0.111 & 0.695 & 0.409 & 0.178 & -0.201 & 0.113 \\
\hline LT & -0.051 & 0.460 & 0.122 & -0.054 & 0.086 & 0.026 & -0.133 & 0.271 \\
\hline PL & 0.410 & -0.034 & 0.279 & 0.414 & 0.567 & 0.115 & -0.334 & 0.211 \\
\hline SK & 0.304 & 0.136 & 0.263 & 0.277 & 0.046 & 0.061 & -0.326 & 0.224 \\
\hline SL & 0.259 & 0.556 & -0.001 & -0.025 & 0.162 & 0.060 & 0.052 & 0.182 \\
\hline BG & 0.110 & 0.655 & -0.232 & 0.418 & 0.341 & -0.063 & -0.248 & 0.164 \\
\hline RO & 0.020 & 0.302 & 0.066 & 0.214 & 0.557 & 0.158 & -0.179 & 0.099 \\
\hline HR & 0.061 & 0.426 & 0.129 & 0.145 & 0.065 & 0.069 & -0.730 & 0.123 \\
\hline
\end{tabular}

Grey colour reveals that the impact of a variable on UPT usage was significant $p<0.05$.

The time from home to the nearest station significantly affects UPT usage in half of the EU countries (11 of 21 countries). The shorter time needed to reach the stop could reduce the total travel time by UPT and it is especially important for people with disabilities [61]. Alternatively, it is a good opportunity to enhance the activity of people. However, to revise the stops and station system is of importance particularly where the time significantly influences UPT usage (e.g., the Czech Republic, Poland, and Romania). Public and other stakeholders should be involved in this process.

Considering other satisfaction categories, the satisfaction of ticket price in half of the EU countries (11 of 21 EU countries) significantly and positively influenced UPT usage. Thus, pricing could be one of the key attributes that attract UPT usage [37,70]. Other authors also revealed that the price level is particularly important in Spain [14] and in the UK [71]. In Greece, increased ticket prices resulted in the reduction of UPT usage [31]. Dickinson and Wretstrand [72] stated that in Sweden adoption of free urban public transport trial periods might be an efficient tool to increase UPT ridership. However, in other EU countries, the satisfaction based on ticket price cannot guarantee the enhancement of UPT usage. Analysing the fare-free public transport programme in Tallinn (Estonia), Hess [73] found that 
public transport "free" exhibited a lower-than-expected increase in ridership. As we see from our results for Estonia, ticket price satisfaction insignificantly influenced the usage of UPT. Thus, we should not expect that the reduction of the ticket price would contribute directly to the enhancement of UPT usage in all EU countries. Other factors might be of importance. For example, the usage of the single ticket approach during all travel by different means of UPT could be much easier for passengers [21]. Furthermore, in the case of price, it is found that costs of using private vehicles in terms of fuel prices or parking costs were related to higher public transport ridership [68]. Thus, it is essential to consider introducing road pricing and higher parking charges simultaneously $[17,73]$ with improvement of other UPT attributes because UPT prices might not be as influential as some results suggest.

A large number of studies have shown that frequency and reliability are important attributes for the satisfaction of urban public transport users $[31,33,52,53,74]$ and are very important for journey time and interchanges $[37,70]$. Comfort and safety are important factors in influencing the usage and UPT service satisfaction as well $[16,32,33,36,44,53,75]$. However, in our case, frequency and reliability, as well as comfort and safety, significantly influenced UPT usage in only one-third of EU countries (7 of 21). This could be because the travel mode used could be considered as a habitual behaviour, carried out without deliberate thinking, automatically, due to repeated use $[16,36,76]$. Dissatisfied passengers due to the lack of transport alternatives have no way of expressing their dissatisfaction [51].

Facilities at the stop were even less significant. The amenities of stops and stations significantly affected UPT usage in only five EU countries: Ireland, Slovenia, Slovakia, Poland and Estonia. According to the other authors' findings, the condition of stations and stops was identified as the strongest factor influencing the overall satisfaction level with urban public transport services $[10,77]$ and influenced satisfaction with the trip [50]. Outwater et al. [78] found that bus stops with modern amenities can significantly determine individuals' choice of transportation modes particularly in adverse weather conditions [79]. The EU has highlighted the requirement for developing and promoting new approaches towards station design [80]. However, this activity might be effective only in the countries where the impact of amenities at stops and stations significantly influenced the usage of UPT. In other words, other UPT attributes which determine UPT usage more significantly should be addressed first or in parallel to enhance UPT.

\section{Conclusions and Policy Implication}

The promotion of UPT usage in the EU is one of the primary tools to reduce environmental impact, traffic, road accidents and noise level, and to seek sustainability in general. So far, EU countries regarding UPT satisfaction are seldom jointly analysed. Research shows that the level of UPT usage in the EU is rather low, and people seldom use public transport. In addition, the usage of UPT significantly is related to the economic development level, and in richer EU countries individuals are less linked to using public transport. It could be related to higher affordability of personal cars in developed countries and the cheaper cost of UPT travel in less-affluent EU countries. These aspects should be considered, as economies of less-affluent countries tend to grow and car ownership increases. Nevertheless, the limitation of this paper is that the usage of UPT is assessed based on self-reported usage. Therefore, data on ridership from UPT companies should be used for specific country, region or city analysis.

We suggest classifying satisfaction to comfort and safety, frequency and reliability, amenities of stops and stations and ticket price. Though all satisfaction categories differed across EU countries, the satisfaction with the ticket price almost in all EU countries was the least. Thus, policymakers, especially on the municipality level, and UPT service providers all over EU should pay particular attention to ticket price level; if these prices were lower, the usage of UPT could be more attractive. On the other hand, UPT services often are already subsidized. Existing experiences (e.g., free ridership programmes) of other countries, should be considered before making decisions regarding the price reductions or refuse. In each case, all satisfaction categories influencing the usage of UPT should be considered and analysed to assess the most important ones. Municipalities and service providers should consider 
public consultations as a tool for UPT enhancement, especially for selecting satisfaction categories to be addressed first. In addition, easy to access and timely transport information, as well as pricing schemes, single ticket approach and e-tickets should be considered by UPT service provides.

Analysing the determinants of UPT usage, we find dissimilar determinants significantly influencing the UPT usage in different EU countries. In half of the EU countries, the time to the nearest stations and the satisfaction of ticket price had significant impacts on the usage of public transport. Addressing these aspects (especially distance to the nearest stop) of UPT might improve the situation in most cases. Meanwhile, the satisfaction with frequency and reliability and comfort and safety significantly effected one-third of EU countries, and only in five EU countries did the amenities of stops and stations influence UPT usage. This might be the case that some attributes are already rather good. Furthermore, these results reveal that improvement of UPT service and separating its categories may not always lead to the enhancement of UPT usage. National peculiarities and UTP usage determinants should be taken into account while making UPT promotion decisions.

Noteworthily, travel mode use could be regarded as a habitual behaviour; dissatisfied passengers due to the lack of transport alternatives have no way of expressing their dissatisfaction and continue to use UPT. Furthermore, the dissatisfaction leads to an increase in the use of personal cars; therefore, next to UPT improvements, municipalities should think about other incentives, such as parking fee and park and ride schemes. However, measures, such as park and ride, in order to be effective should be profoundly considered and analysed before implementation.

If quality of urban public transport mostly is the responsibility of local policymakers, municipalities and service providers, the overall promotion of UPT should be part of national and EU policies. This could include enhancing the image of public transport users (especially young ones and men) and incentives for lower car use (e.g., higher road and fuel prices), as well as raising awareness about health and environmental impacts.

Author Contributions: A.M. search and analyzed the data; G.L. analysis tools; R.D. and G.L. wrote the paper. G.L. is a supervisor of this paper preparation. All authors have read and agreed to the published version of the manuscript.

Funding: This research received no external funding.

Acknowledgments: We thank the anonymous reviewers for their constructive comments.

Conflicts of Interest: The authors declare no conflict of interest.

\section{References}

1. Cruz, I.S.; Katz-Gerro, T. Urban public transport companies and strategies to promote sustainable consumption practices. J. Clean. Prod. 2016, 123, 28-33. [CrossRef]

2. Zailani, S.; Iranmanesh, M.; Masron, T.A.; Chan, T.-H. Is the intention to use public transport for different travel purposes determined by different factors? Transp. Res. Part D 2016, 49, 18-24. [CrossRef]

3. Siskos, P.; Zazias, G.; Petropoulos, A.; Evangelopoulou, S.; Capros, P. Implications of delaying transport decarbonisation in the EU: A systems analysis using the PRIMES model. Energy Policy 2018, 121, 48-60. [CrossRef]

4. Letnik, T.; Marksel, M.; Luppino, G.; Bardi, A.; Bozicnik, S. Review of policies and measures for sustainable and energy efficient urban transport. Energy 2018, 163, 245-257. [CrossRef]

5. Woods, R.; Masthoff, J. Comparison of car driving, public transport and cycling experiences in three European cities. Transp. Res. Part A 2017, 103, 211-222. [CrossRef]

6. Dirgahayani, P. Environmental co-benefits of public transportation improvement initiative: The case of Trans-Jogja bus system in Yogyakarta, Indonesia. J. Clean. Prod. 2013, 58, 74-81. [CrossRef]

7. Replogle, M.E.; Fulton, L. A Global High Shift Scenario, Impacts and Potential for More Public Transport, Walking, and Cycling with Lower Car Use; Institue for Transportation and Development Policy (ITDP): New York, NY, USA, 2014.

8. Aggarwal, P.; Jain, S. Energy demand and CO2 emissions from urban on-road transport in Delhi: Current and future projections under various policy measures. J. Clean. Prod. 2016, 128, 48-61. [CrossRef] 
9. Liu, H.; Zhang, Y.; Zhu, Q.; Chu, J. Environmental efficiency of land transportation in China: A parallel slack-based measure for regional and temporal analysis. J. Clean. Prod. 2017, 142, 867-876. [CrossRef]

10. Abenoza, R.F.; Cats, O.; Susilo, Y.O. Travel satisfaction with public transport: Determinants, user classes, regional disparities and their evolution. Transp. Res. Part A 2017, 95, 64-84. [CrossRef]

11. Chen, Y.; Bouferguene, A.; Li, H.X.; Liu, H.; Shen, Y.; Al-Hussein, M. Spatial gaps in urban public transport supply and demand from the perspective of sustainability. J. Clean. Prod. 2018, 195, 1237-1248. [CrossRef]

12. Lucas, K.; Jones, P. Social impacts and equity issues in transport: An introduction. J. Transp. Geogr. 2012, 21, 1-3. [CrossRef]

13. Margarita, A.; Evangelos, G.; Hafieda, L.-A.; Aristotelis, N. The effect of major market and societal trends on public transport in European cities. Transp. Res. Procedia 2017, 24, 105-112. [CrossRef]

14. Cascajo, R.; Olvera, L.D.; Monzon, A.; Plat, D.; Ray, J.-B. Impacts of the economic crisis on household transport expenditure and public transport policy: Evidence from the Spanish case. Transp. Policy 2018, 65, 40-50. [CrossRef]

15. Hiselius, L.W.; Rosqvist, L.S. Mobility Management campaigns as part of the transition towards changing social norms on sustainable travel behavior. J. Clean. Prod. 2016, 123, 34-41. [CrossRef]

16. Mugion, R.G.; Toni, M.; Raharjo, H.; Pietro, L.D.; Sebathu, S.P. Does the service quality of urban public transport enhance sustainable mobility? J. Clean. Prod. 2018, 174, 1566-1587. [CrossRef]

17. Nguyen-Phuoc, D.Q.; Currie, G.; Gruyter, C.D.; Young, W. How do public transport users adjust their travel behaviour if public transport ceases? A qualitative study. Transp. Res. Part F 2018, 54, 1-14. [CrossRef]

18. Abenoza, R.F.; Cats, O.; Susilo, Y.O. How does travel satisfaction sum up? An exploratory analysis in decomposing the door-to-door experience for multimodal trips. Transportation 2019, 46, 1615-1642. [CrossRef]

19. Eurostat. Themes/Transport. 2012. Available online: http://epp.eurostat.cec.eu.int (accessed on 15 May 2020).

20. European Platform on Mobility Management. TEMS Database EPOMM. 2014. Available online: http: //www.epomm.eu (accessed on 8 August 2020).

21. Bryniarska, Z.; Zakowska, L. Multi-criteria evaluation of public transport interchanges. Transp. Res. Procedia 2017, 24, 25-32. [CrossRef]

22. EU Commissions. METPEX: Report on Survey and Data Collection Processes at Each Location (Deliverable of the METPEX Project); EU Commissions: Brussels, Belgium, 2014.

23. Susilo, Y.O.; Cats, O. Exploring key determinants of travel satisfaction for multi-modal trips by different traveler groups. Transp. Res. Part A 2014, 67, 366-380. [CrossRef]

24. Susilo, Y.O.; Cats, O.; Diana, M.; Hrin, G.R.; Woodcock, A. Implementing a behavioural pilot survey for the stage-based study of the whole journey traveller experience. Transp. Res. Procedia 2015, 11, 172-184. [CrossRef]

25. Susilo, Y.O.; Woodcock, A.; Liotopoulos, F.; Duarte, A.; Osmond, J.; Abenoza, R.F.; Pirra, M. Deploying traditional and smartphone app survey methods in measuring door-to-door travel satisfaction in eight European cities. Transp. Res. Procedia 2017, 25, 2257-2275. [CrossRef]

26. Susilo, Y.O.; Abenoza, R. METPEX trial result. In Designing Mobility and Transport Services; Tovey, M., Woodcock, A., Osmond, J., Eds.; Taylor and Francis: London, UK, 2017; pp. 126-146.

27. Diana, M.; Duarte, A.; Pirra, M. Transport Quality Profiles of European Cities Based on a Multidimensional Set of Satisfaction Ratings Indicators. Transp. Res. Rec. J. Transp. Res. Board 2017, 2643, 84-92. [CrossRef]

28. Pirra, M.; Pensa, R.G. Comparing Transport Quality Perception among Different Travellers in European Cities through Co-Cluster Analysis. Sustainability 2019, 11, 7159. [CrossRef]

29. Woodcock, A.; Tovey, M. Designing Whole Journey, Multimodal Transport Provision. Des. J. 2020, $23,91-112$. [CrossRef]

30. Thomaz, P.S.; Nogueira, C.M.; Costa, L. Satisfaction with public transport: The case of an university access. Int. J. Eng. Res. Appl. 2016, 6, 1-6.

31. Efthymiou, D.; Antoniou, C. Understanding the effects of economic crisis on public transport users' satisfaction and demand. Transp. Policy 2017, 53, 89-97. [CrossRef]

32. Chica-Olmo, J.; Gachs-Sánchez, G.S.; Lizarraga, C. Route effect on the perception of public transport services quality. Transp. Policy 2018, 67, 40-48. [CrossRef]

33. Ngoc, A.M.; Hung, K.; Tuan, V.A. Towards the Development of Quality Standards for Public Transport Service in Developing Countries: Analysis of Public Transport Users' Behavior. Transp. Res. Procedia 2017, 25, 4560-4579. [CrossRef] 
34. Fellesson, M.; Friman, M. Perceived satisfaction with public transport service in nine European cities. J. Transp. Res. Forum 2008, 47, 93-104. [CrossRef]

35. Lois, D.; Monzón, A.M.; Hernández, H.S. Analysis of satisfaction factors at urban transport interchanges: Measuring travellers' attitudes to information, security and waiting. Transp. Policy 2018, 67, 49-56. [CrossRef]

36. Şimşekoğlu, Ö.; Nordfjærn, T.; Rundmo, T. The role of attitudes, transport priorities, and car use habit for travel mode use and intentions to use public transportation in an urban Norwegian public. Transp. Policy 2015, 42, 113-120. [CrossRef]

37. Chowdhury, S.; Ceder, A. Users' willingness to ride an integrated public-transport service: A literature review. Transp. Policy 2016, 48, 183-195. [CrossRef]

38. Friman, M.; Gärling, T. Frequency of negative critical incidents and satisfaction with public transport services. II. J. Retail. Consum. Serv. 2001, 8, 105-114. [CrossRef]

39. Gärling, T.; Bamberg, S.; Friman, M. The role of attitude in choice of travel, satisfaction with travel, and change to sustainable travel. In Handbook of Attitudes: Applications; Albarracin, D., Johnson, B.T., Eds.; Routledge: London, UK, 2018.

40. Fornell, C.A. National customer satisfaction barometer: The Swedish experience. J. Mark. 1992, 56, 1-18. [CrossRef]

41. Morfoulaki, M.; Tyrinopoulos, Y.; Aifadopoulou, G. Estimation of satisfied customers in public transport systems: A new methodological approach. J. Transp. Res. Forum 2010, 46. [CrossRef]

42. Eboli, L.; Mazzulla, G. Service quality attributes affecting customer satisfaction for bus transit. J. Public Transp. 2007, 10, 2. [CrossRef]

43. Tyrinopoulos, Y.; Aifadopoulou, G. A complete methodology for the quality control of passenger services in the public transport business. Eur. Transp. Trasp. Eur. 2008, 38, 1-16.

44. Le-Klähn, D.T.; Hall, C.M.; Gerike, R. Analysis of visitor satisfaction with public transport in Munich. J. Public Transp. 2014, 17, 5. [CrossRef]

45. Imam, R. Measuring public transport satisfaction from user surveys. Int. J. Bus. Manag. 2014, 9, 106. [CrossRef]

46. Ettema, D.; Friman, M.; Gärling, T.; Olsson, L.E.; Fujii, S. How in-vehicle activities affect work commuters' satisfaction with public transport. J. Transp. Geogr. 2012, 24, 215-222. [CrossRef]

47. Fiorio, C.V.; Florio, M.; Perucca, G. User satisfaction and the organization of local public transport: Evidence from European cities. Transp. Policy 2013, 29, 209-218. [CrossRef]

48. St-Louis, E.; Manaugh, K.; van Lierop, D.; El-Geneidy, A. The happy commuter: A comparison of commuter satisfaction across modes. Transp. Res. Part F 2014, 26, 160-170. [CrossRef]

49. De Oña, J.; de Oña, R. Quality of service in public transport based on customer satisfaction surveys: A review and assessment of methodological approaches. Transp. Sci. 2015, 49, 605-622. [CrossRef]

50. Frimana, M.; Gärling, T.; Ettema, D. Improvement of public transport services for non-cycling travellers. Travel Behav. Soc. 2019, 16, 235-240. [CrossRef]

51. Mouwen, A. Drivers of customer satisfaction with public transport services. Transp. Res. Part A 2015, 78, 1-20. [CrossRef]

52. Jenelius, E. Public transport experienced service reliability: Integrating travel time and travel conditions. Transp. Res. Part A 2018, 117, 275-291. [CrossRef]

53. Irtema, H.I.M.; Ismail, A.; Borhan, M.N.; Das, A.M.; Alshetwi, A.B.Z. Case study of the behavioural intentions of public transportation passengers in Kuala Lumpur. Case Stud. Transp. Policy 2018, 6, 462-474. [CrossRef]

54. Beirão, G.; Cabral, J.S. Understanding attitudes towards public transport and private car: A qualitative study. Transp. Policy 2007, 14, 478-489. [CrossRef]

55. Cats, O.; Abenoza, R.F.; Liu, C.; Susilo, Y.O. Evolution of Satisfaction with Public Transport and Its Determinants in Sweden. Transp. Res. Rec. J. Transp. Res. Board 2015, 2538, 86-95. [CrossRef]

56. AlRukaibi, F.; AlKheder, S. Optimization of bus stop stations in Kuwait. Sustain. Cities Soc. 2019, 44, 726-738. [CrossRef]

57. Brons, M.; Rietveld, P. Access to railway stations and its potential in increasing rail use. Transp. Res. Part A 2009, 43, 136-149. [CrossRef]

58. Mees, P. Transport for Suburbia: Beyond the Automobile Age; Earthscan: London, UK, 2010.

59. Kingham, S.; Dickinson, J.; Copsey, S. Travelling to work: Will people move out of their cars. Transp. Policy 2011, 8, 151-160. [CrossRef] 
60. Galdames, C.; Tudela, A.; Carrasco, J.A. Exploring the role of psychological factors in mode choice models by a latent variables approach. Transp. Res. Rec. 2011, 2230, 68-74. [CrossRef]

61. Truong, L.T.; Somenahalli, S.V.C. Exploring frequency of public transport use among older adults: A study in Adelaide, Australia. Travel Behav. Soc. 2015, 2, 148-155. [CrossRef]

62. Yang, Y.; Xu, Y.; Rodriguez, D.A.; Michael, Y.; Zhang, H. Active travel, public transportation use, and daily transport among older adults: The association of built environment. J. Transp. Health 2018, 9, 288-298. [CrossRef]

63. Flash Eurobarometer. Future of Transport. Analytical Report; Flash EB Series \#312; The Gallup Organisation: Budapest, Hungary, 2011.

64. Buehler, R.; Pucher, J. Demand for public transport in Germany and the USA: An analysis of rider characteristics. Transp. Rev. 2012, 32, 541-567. [CrossRef]

65. European Commission. Europeans' Satisfaction of with Urban Transport. Report; Flash Eurobarometer 382, 153; European Commission: Brussels, Belgium, 2014.

66. Nunnally, J.C.; Bernstein, I.H. Psychometric Theory, 3rd ed.; McGraw-Hill: New York, NY, USA, 1994.

67. Hair, J.F.; Black, B.; Babin, B.; Anderson, R.E.; Tatham, R.L. Multivariate Data Analysis: A Global Perspective; Pearson Education Inc.: Hoboken, NJ, USA, 2010.

68. Ingvardson, J.B.; Nielsen, O.A. How urban density, network topology and socio-economy influence public transport ridership: Empirical evidence from 48 European metropolitan areas. J. Transp. Geogr. 2018, 72, 50-63. [CrossRef]

69. Fiorio, C.V.; Percoco, M. Would you stick to using your car even if charged? Evidence from Trento, Italy. Transp. Rev. 2007, 27, 605-620. [CrossRef]

70. Redman, L.; Friman, M.; Garling, T.; Hartig, T. Quality attributes of public transport that attract car users: Are search review. Transp. Policy 2013, 25, 119-127. [CrossRef]

71. Paulley, N.; Balcombe, R.; Mackett, R.; Titheridge, H.; Preston, J.; Wardman, M.; Shires, J.; White, P. The demand for public transport: The effects of fares, quality of service, income and car ownership. Transp. Policy 2006, 13, 295-306. [CrossRef]

72. Dickinson, J.; Wretstrand, A. Att styra mot ökad kollektivtrafikandel. En kunskapsöversikt. K2 Res. 2015, 2, K2. (In Swedish)

73. Hess, D.B. Decrypting fare-free public transport in Tallinn, Estonia. Case Stud. Transp. Policy 2017, 5, 690-698. [CrossRef]

74. Chakrabarti, S.; Giuliano, G. Does service reliability determine transit patronage? Insights from the Los Angeles Metro bus system. Transp. Policy 2015, 42, 12-20. [CrossRef]

75. Dell'Olio, L.; Ibeas, A.; Cecin, P. The quality of service desired by public transport users. Transp. Policy 2011, 18, 217-227. [CrossRef]

76. Chen, C.F.; Chao, W.H. Habitual or reasoned? Using the theory of planned behavior, technology acceptance model, and habit to examine switching intentions toward public transit. Transp. Res. Part F Traffic Psychol. Behav. 2011, 14, 128-137. [CrossRef]

77. Wong, R.C.P.; Szeto, W.Y.; Yang, L.; Li, Y.C.; Wong, S.C. Elderly users' level of satisfaction with public transport services in a high-density and transit-oriented city. J. Transp. Health 2017, 7, 209-217. [CrossRef]

78. Outwater, M.L.; Spitz, G.; Lobb, J.; Campbell, M.; Sana, B.; Pendyala, R.; Woodford, W. Characteristics of premium transit services that affect mode choice. Transportation 2011, 38, 605-623. [CrossRef]

79. Miao, Q.; Welch, E.W.; Sriraj, P.S. Extreme weather, public transport ridership and moderating effect of bus stop shelters. J. Transp. Geogr. 2019, 74, 125-133. [CrossRef]

80. Hoeven, F.; Juchnevic, K. The significance of the underground experience: Selection of reference design cases from the underground public transport stations and interchanges of the European Union. Tunn. Undergr. Space Technol. 2016, 55, 176-193. [CrossRef]

Publisher's Note: MDPI stays neutral with regard to jurisdictional claims in published maps and institutional affiliations. 